\title{
PENGEMBANGAN MEDIA VIDEO PEMBELAJARAN MATERI PASSING BOLAVOLI SMP KELAS VII
}

\author{
Markus Dominique Simbolon ${ }^{1}$, H. Wahjoedi², Ni Luh Putu Spyanawati ${ }^{3}$ \\ Prodi Pendidikan Jasmani Kesehatan dan Rekreasi \\ Jurusan Pendidikan Olahraga \\ Fakultas Olahraga dan Kesehatan \\ Universitas Pendidikan Ganesha \\ Email: markusdominiquesimbolon@gmail.com,wahjoedi@undiksha.ac.id, \\ putu.spyanawati@undiksha.ac.id
}

\begin{abstract}
ABSTRAK
Penelitian ini bertujuan untuk mengembangkan produk media pembelajaran berupa media video pembelajaran materi passing bolavoli untuk kelas VII SMP Negeri 4 Singaraja. Model pengembangan yang digunakan adalah model ADDIE meliputi 5 tahap yaitu: tahap Analisis (Analyze), Perancangan (Design), Pengembangan (Development), Penerapan (Implementation), dan Evaluasi (Evaluation). Metode pengumpulan data yang digunakan dalam penelitian ini adalah wawancara, pencatatan dokumen dan kuesioner. Prosedur validasi media video yaitu diawali dengan uji ahli isi mata pelajaran, ahli desain pembelajaran, ahli media pembelajaran. Data dianalisis dengan teknik analisis deskriptif kualitatif dan analisis deskriptif kuantitatif. Hasil penelitian berdasarkan tanggapan para ahli yaitu Ahli Isi Pembelajaran 90\% (Sangat Baik), Ahli Media Pembelajaran 95\% (Sangat Baik) dan Ahli Desain Pembelajaran 94\% (Sangat Baik). Selama proses pengembangan, aspek yang diperbaiki adalah intensitas Penyempurnaan media pada video dari tanggapan para Ahli. Dari hasil diatas maka dapat dikatakan bahwa media video pembelajaran dengan model ADDIE materi passing bolavoli dapat dikatakan valid dan dapat digunakan untuk mendukunng proses pembelajaran atau penelitian lebih lanjut.
\end{abstract}

Kata Kunci: pengembangan, video pembelajaran, ADDIE, passing Bolavoli.

\begin{abstract}
ABSTRAC
This study aims to develop instructional media products in the form of video learning media for volleyball passing material for class VII SMP Negeri 4 Singaraja. The development model used is the ADDIE model which includes 5 stages, namely: the Analyze, Design, Development, Implementation, and Evaluation stages. Data collection methods used in this study were interviews, document recording and questionnaires. The video media validation procedure begins with a subject content expert test, learning design expert, learning media expert. Data were analyzed using qualitative descriptive analysis techniques and quantitative descriptive analysis. The results of the study were based on the responses of experts, namely Learning Content Experts 90\% (Very Good), Learning Media Experts 95\% (Very Good) and Learning Design Experts 94\% (Very Good). During the development process, the aspect that was improved was the intensity of the refinement of the media on the video from the responses of the Experts. From the results above, it can be said that the instructional video media with the ADDIE model of volleyball passing material can be said to be valid and can be used to support the learning process or further research.
\end{abstract}

Keywords: development, instructional videos, ADDIE, volleyball passing. 


\section{PENDAHULUAN}

Pendidikan jasmani olahraga dan kesehatan (PJOK) pada dasarnya yaitu proses pendidikan yang mayoritas menggunakan aktivitas fisik didalam pembelajarannya. PJOK dianggap mempunyai pengaruh penting dalam dunia pendidikan dan masyarakat, pentingnya olahraga ini diterapkan disekolah dapat dilihat dari tujuan pembelajaran PJOK yang mencakup berbagai aspek yaitu: aspek kognitif, aspek afektif dan aspek psikomotorik. Pada aspek kognitif tidak saja menyangkut penguasaan pengetahuan, akan tetapi hal tersebut meliputi juga pemahaman terhadap segala gerak pada pembelajarannya. Pada aspek afektif bertujuan untuk mengembangkan konsep diri dan komponen kepribadian seperti emosional dan watak karakter setiap individu peserta didik. Sedangkan pada aspek psikomotorik, bertujuan untuk dapat memanfaatkan aktivitas fisik yang berguna meningkatkan kemampuan kebugaran jasmani serta pembentukan penguasaan gerak keterampilan dalam pembelajaran. Untuk mencapai tujuan dari PJOK itu sendiri, maka penting pula adanya penyesuaian materi pembelajaran didalamnya.

Guru sebagai salah satu sumber belajar diharapkan harus paham dan mengerti tentang materi pembelajaran serta memahami sifat dan karakteristik setiap peserta didik dalam membentuk situasi belajar yang kondusif untuk meningkatkan keaktifan peserta didik dalam proses pembelajaran yang berlangsung agar dapat memenuhi tujuan yang ingin dicapai seperti diatas. Keberhasilan tersebut dapat dilihat dari tingkat pemahaman dan hasil belajar peserta didik. Semakin tinggi tingkat keberhasilan pemahaman dan penguasaan materi, semakin tinggi pula tingkat keberhasilan proses pembelajaran tersebut.
Pada mata pelajaran PJOK terdapat beberapa materi, salah satunya yaitu materi permainan bolavoli. Menurut Budhiarta (2008:1), mengatakan bahwa "permainan bolavoli yaitu olahraga yang dimainkan oleh anak-anak sampai orang dewasa baik wanita maupun pria". Menurut Nuril (2007:20), mengatakan bahwa "permainan bolavoli merupakan suatu permainan yang kompleks, sebab dibutuhkan koordinasi gerak yang benar-benar bisa diandalkan untuk melaukan semua gerakan di dalam permainan voli”. Menurut Yunus (1992:108), mengatakan bahwa "permainan bolavoli adalah olahraga yang dimainkan oleh dua tim dalam lapangan yang dipisahkan oleh sebuah net". Maka dapat disimpulkan permainan bolavoli adalah olahraga yang dimainkan oleh dua tim dalam lapangan yang dipisahkan oleh sebuah net serta dimainkan oleh 6 orang dalam 1 tim.

Dalam pembelajaran bolavoli pada dasarnya mempunyai teknikteknik dasar, salah satunya yaitu teknik dasar passing. Menurut Nuril (2007: 22), mengatakan bahwa "passing adalah upaya seorang pemain dengan mengunakan suatu teknik tertentu untuk mengoperkan bola yang dimainkannya kepada teman seregunya untuk dimainkan dilapangan sendiri". Menurut Budhiarta (2008:3), mengatakan bahwa "passing adalah pukulan bola pertama setelah bola itu berada dalam permainan akibat dari serangan, sevis lawan atau permainan net". Menurut Yunus (1992:122), mengatakan bahwa "passing adalah mengoper bola kepada teman sendiri dalam satu regu dengan suatu teknik tertentu, sebagai langkah awal untuk menyusun pola serangan kepada regu lawan". Maka dapat disimpulkan passing adalah pukulan yang dilakukan pada teman sendiri dan 
dilapangan sendiri yang bertujuan untuk mengatur pola serangan. Dalam proses pembelajaran, guru diharapkan memiliki multi peran sehingga mampu menciptakan kondisi belajar mengajar yang efektif dan memotivasi agar dapat diterima dan diterapkan oleh peserta didik, sehingga tujuan proses belajar mengajar dapat tercapai. Melalui pembelajaran PJOK diharapkan dapat meningkatkan mutu pendidikan, akan tetapi diperlukan upaya adanya media pembelajaran, sarana dan prasarana yang mendukung, dan juga bahan ajar yang digunakan sesuai dengan kurikulum yang berlaku agar mampu mencapai peyempurnaan pembelajaran berlangsung.

Media sangat diperlukan dalam pembelajaran sebagai alat penyampaian informasi dan pesan dari guru kepada peserta didik. Pembelajaran yang baik dan berlangsung lancar memerlukan media pembelajaran yang baik dan sesuai dengan kondisi kelas pembelajaran secara online. Pada materi teknik dasar passing bolavoli merupakan pembelajaran produktif atau praktik sehingga membutuhkan media yang mengandung unsur gerak. Oleh karena itu, video pembelajaran merupakan salah satu media yang sesuai untuk menampilkan tahap-tahap dalam proses pembelajaran PJOK khususnya dapat merangsang pikiran, perasaan, minat, serta perhatian dari peserta didik terhadap materi yang disampaikan khsusunya dalam pembelajaran online. Media video pembelajaran diartikan sebagai segala format media elektronik yang digunakan untuk merangsang pikiran, perasaan dan minat peserta didik untuk belajar melalui penayangan ide atau gagasan, pesan dan informasi gambar bergerak. Sehingga media video ini dapat membantu pada proses pembelajaran yang dapat diterapkan dengan baik dan membuat peserta didik dapat lebih mudah memahami materi yang dibahas. Media video pembelajaran sangat perlu diterapkan dalam proses pembelajaran, terutama pada materi teknik dasar passing bolavoli yang dibutuhkan disekolah tersebut karena dapat digunakan sebagai sumber belajar mandiri secara online, mempermudah peserta didik dalam memahami materi teknik dasar passing bolavoli sehingga proses pembelajaran lebih efektif dan efisien.

Hal ini dikuatkan oleh penelitian yang dilakukan oleh I Gede Suwiwa (2014) dimana hasil penelitian menunjukkan bahwa validasi bahan ajar ditinjau dari aspek isi adalah sangat baik dengan persentase $100 \%$, aspek media isi adalah sangat baik dengan persentase $100 \%$, aspek media komputer adalah baik dengan persentase $79.45 \%$, aspek disain pembelajaran adalah baik dengan persentase $87 \%$. Hasil uji perorangan adalah sangat baik dengan persentase $94,3 \%$, hasil uji kelompok kecil adalah sangat baik dengan persentase $91,4 \%$, hasil uji lapangan sangat baik dengan persentase $94 \%$, dan hasil uji dosen mata kuliah adalah sangat baik dengan persentase 90,8\%.

Penelitian Miftakul Sokheh (2017) menunjukkan bahwa ditinjau dari aspek isi mendapatkan persentase $88,00 \%$ berarti, video pembelajaran ini berada pada kategori baik. Kualitas media ditinjau dari aspek media mendapatkan persentase $96,00 \%$ berarti, video pembelajaran ini berada pada kategori sangat baik. Kualitas media ditinjau dari aspek desain mendapatkan persentase $84,00 \%$ berarti, video pembelajaran ini berada pada kategori baik. Hasil uji perorangan mendapatkan persentase $94,67 \%$ berarti, media pembelajaran ini dalam kategori sangat baik. Hasil uji kelompok kecil mendapatkan persentase $89,34 \%$ berarti, video 
pembelajaran ini dalam kategori sangat baik. Hasil uji lapangan mendapatkan persentase $91,21 \%$ berarti video pembelajaran ini dalam kategori sangat baik.

I Gede Handika Putra (2017) melalui penelitiannya menunjukkan bahwa ditinjau dari aspek isi mendapatkan persentase $96 \%$ berarti, video pembelajaran ini berada pada kategori sangat baik. Kualitas media ditinjau dari aspek desain pembelajaran dengan persentase $85 \%$ berarti, video pembelajaran ini berada pada kategori baik. Kualitas media ditinjau dari aspek media pembelajaran termasuk kriteria dengan persentase $80 \%$ berarti, video pembelajaran ini berada pada kategori baik.

Berdasarkan penelitian diatas maka dapat disimpulkan bahwa media video pembelajaran sangat penting untuk peningkatan hasil belajar peserta didik dalam proses belajar. Mengingat begitu pentingnya materi passing bolavoli bagi peserta didik serta kendala yang dialami didalam pembelajaran online, maka sangatlah diperlukan suatu pengembangan media video pembelajaran yang dapat mengakomodasi kebutuhan peserta didik dalam meningkatkan motivasi belajar peserta didik, sehingga membuat peserta didik SMP Negeri 4 Singaraja di Kelas VII mampu melakukan tugas gerak yang diberikan guru sesuai dengan yang ada di video pembelajaran.

Berdasarkan permasalahan diatas, mendorong peneliti untuk membuat sebuah penelitian yang berjudul "Pengembangan Media Video Pembelajaran Materi Passing BolaVoli Kelas VII SMP Negeri 4 Singaraja" yang dapat dijadikan sebagai alternatif memperbaiki mutu pembelajaran pada materi passing bolavoli.

\section{METODE PENELITIAN}

Penelitian ini merupakan jenis penelitian pengembangan. Penelitian pengembangan adalah suatu jenis penelitian yang bertujuan untuk mengembangkan dan menghasilkan suatu produk. Produk penelitian ini adalah berupa video pembelajaran pada materi passing bolavoli untuk siswa SMP kelas VII. Desain pengembangan video pembelajaran dalam penelitian ini diadaptasi dari model pengembangan ADDIE yang terdiri atas lima tahap pengembangan yaitu analyze, design, development, implementation, evaluation. Namun dalam hal ini untuk tahap implementation, evaluation tidak dilakukan hanya sampai kepada uji ahli, maka diberikan kesempatan bagi peneliti lain untuk meneliti lebih lanjut.

Produk berupa video pembelajaran dalam bentuk Video MP4, sebagai hasil dari penelitian pengembangan ini diuji tingkat validitas. Tingkat validitas media video pembelajaran diketahui melalui hasil analisis kegiatan uji kepada beberapa ahli, yakni: a) Tahap review ahli, Pada tahap ini subjek uji coba terdiri dari satu orang ahli isi bidang studi atau mata pelajaran bolavoli, satu orang ahli desain pembelajaran dan ahli media pembelajaran. Ahli isi bidang studi atau mata pelajaran dalam penelitian ini adalah seorang dosen ahli bidang studi dengan spesifikasi minimal sarjana (S2). Ahli desain pembelajaran adalah seorang teknologi pembelajaran dengan spesifikasi minimal sarjana (S2), dan satu orang ahli media pembelajaran dengan spesifikasi minimal sarjana (S2) Teknologi Pendidikan di Universitas Pendidikan Ganesha (UNDIKSHA).

\section{HASIL DAN PEMBAHASAN}

Penelitian ini dilaksanakan di SMP Negeri 4 Singaraja. Oleh karena itu, peneliti mengembangkan media pembelajaran berupa video 
pembelajaran yang diharapkan dapat mengatasi permasalahan yang ada disekolah tersebut menggunakan model pengembangan ADDIE yang menghasilkan desain berupa storyboard dan flowchart. Adapun tahapan uji coba yang telah dilakukan yaitu uji coba para ahli. Semua tahapan tersebut dilakukan guna menyempurnakan media video pembelajaran pada materi teknik dasar passing bolavoli. Adapun hasil data dan analisis media video pembelajaran sebagai berikut:

Tabel 1. Hasil analisis kualifikasi media

\begin{tabular}{llll}
\hline No. & Responden & Nilai (\%) & Kualifikasi \\
\hline 1 & Ahli Isi Mata Pelajaran & $90 \%$ & Sangat Baik \\
2 & $\begin{array}{l}\text { Ahli } \\
\text { Pembelajaran }\end{array}$ & Media $95 \%$ & Sangat Baik \\
3 & $\begin{array}{l}\text { Ahli } \\
\text { Pembelajaran }\end{array}$ & Desain $94 \%$ & Sangat Baik \\
\hline
\end{tabular}

Berdasarkan hasil penelitian yang telah dilakukan dengan menggunakan model ADDIE pada media video pembelajaran passing bolavoli hanya sampai tahap pengembangan saja, untuk tahap implementasi dan evaluasi tidak dilakukan, maka peneliti memberikan kesempatan kepada peneliti lain untuk bisa meneliti lebih lanjut pada tahap tersebut. Hasil dari para ahli terhadap penilaian melalui validasi media video pembelajaran pada materi teknik dasar passing bolavoli dianggap valid dan layak menurut uji coba para ahli. Hal ini didukung dari kajian teori mengenai penggunaan media video pada proses pembelajaran serta didukung dengan hasil penelitian terdahulu mengenai media video yang dapat mempermudah peserta didik dalam memahami pembelajaran sehingga hasil belajar juga meningkat, yaitu penelitian yang dilakukan oleh: 1) Penelitian I Gede Suwiwa (2014) yang berjudul "Pengembangan Multimedia Interaktif Pembelajaran pada Mata Kuliah Teori dan Praktik Pencak Silat", 2) Penelitian Miftakul Shokeh (2017) yang berjudul "Pengembangan Media Video
Pembelajaran dengan Model ADDIE Passing Bola Basket".

3) Penelitian Eka Nugraha Marfiska Ganantara (2016) yang berjudul "Pengembangan Media Pembelajaran Menggunakan Video Simulasi Mata Pelajaran Pendidikan Jasamani kesehatan dan Olahraga Pada Siswa Kelas X SMKN 1 Bancak".

Dengan demikian media video pembelajaran pada materi teknik dasar passing bolavoli dapat membantu proses pembelajaran secara online, mempermudah peserta didik memahami materi yang diajarkan. Sehingga pembelajaran menjadi lebih menarik dan menajdi lebih interaktif serta dapat meningkatkan hasil belajar peserta didik. Pembelajaran menjadi lebih menarik karena adanya pengembangan media video pembelajaran dan kegiatan belajar secara onlie menjadi lebih interaktif.

\section{PENUTUP}

Berdasarkan hasil pembahasan dan analisis yang telah dilakukan pada bab sebelumnya, dapat ditarik kesimpulan bahwa:

(1) Pada rancangan video pembelajaran ini, menggunakan 
model ADDIE (analyze, design, development, implementation, evaluation) dan telah dihasilkan sebuah media video pembelajaran dengan materi passing bola voli yang diperuntukkan bagi peserta didik kelas VII SMP Negeri 4 Singaraja dan layak digunakan.

(2) Kualitas media video pembelajalan, penelitian pengembangan ini telah menghasilkan sebuah media dengan hasil penelitian atau uji coba sebagai berikut. a) ahli isi/materi materi pelajaran dengan tingkat pencapaian $90 \%$ pada kategori sangat baik, b) ahli media pembelajaran dengan tingkat pencapaian $95 \%$ pada kategori sangat baik, c) ahli desain video pembelajaran dengan tingkat pencapaian 94\% pada kategori sangat baik.

Secara umum telah mampu menjawab rumusan masalah. Dari kegiatan uji ahli yang telah dilaksanakan dan hasil angket yang disebar. Selain itu, media video pembelajaran ini membuat peserta didik menjadi lebih mudah untuk memahami materi pelajaran. Maka dapat disimpulkan bahwa video pembelajaran pada materi passing bolavoli layak pakai sesuai dengan karakteristik peserta didik kelas VII SMP Negeri 4 Singaraja.

Selain kesimpulan, ada juga beberapa saran yang dipaparkan yaitu:

(1) Bagi guru media ini dapat dijadikan sumber belajar yang efektif dan efisien serta sumber belajar mandiri dalam mata pelajaran PJOK khususnya bagi peserta didik SMP Negeri 4 Singaraja.

(2) Bagi peneliti lainnya, produk pengembangan ini sebaiknya dikembangkan lebih lanjut pada materi-materi pelajaran yang lain.

(3) Media pembelajaran dalam bentuk video pembelajaran ini berbasis gambar-gambar, video, dan dilengkapi dengan audio untuk memudahkan pemahaman materi terutama materi-materi yang sulit di pahami bila hanya menggunakan tulisan dengan gambar atau foto.

\section{DAFTAR PUSTAKA}

Ari, anti dkk. (2017). "Steganografi Pada Video Menggunakan Metode Least Significant Bit (LSB) Dan End Of File (EOF)". Jurnal Informatika Mulawarman. Volume. 12, No.2, hlm (104-108).

Budhiarta, Danu. 2008. Teori Praktik Permainan Bolavoli dan Bolavoli Pantai.Jurusan Penjaskesrek FOK Undiksha.

Dimyati dan Mudjiono. 2009. Belajar danPembelajaran. Jakarta: PT Rineka Cipta.

Hamalik, oemar. 2012. Kurikulum dan Pembelajaran. Jakarta: Bumi Aksara.

Hamalik, oemar. 1989. Media Pendidikan. Bandung: PT. Citra Aditya Bakti.

Hamdanillah, dkk. (2017). "Pengaruh Model Pembelajaran Advance

Orcanizer Menggunakan Video Pembelajaran

Terhadap Hasil Belajar Fisika Peserta Didik Kelas Xl". Jurnal Pendidikan Fisika dan Teknologi.Volume 3 No.2, hlm (119-127).

Haryoko, sapto. (2009). "Efektifitas Pemanfaatan Media AudioVisual Sebagai Alternatif 
Optimalisasi Model

Pembelajaran". Jurnal

EdukasiElektro. Volume 5, No 1, $\mathrm{hlm}(1-10)$.

Husdarta, H. J. S. 2009. Manajemen pendidikan jasmani. Bandung: Alfabeta.

Koestadi, Cecep dan Sutjipto, Bambang. 2011. Media Pembelajaran Manual dan Digital. Bogor : Ghalia Indonesia.

Mandalawati, kuntum. (2017). "Meningkatkan Kemampuan Passing Pada Olahraga Bola Voli Melalui "Pog" Untuk Mahasiswa Pgsd". Prosiding Seminar Nasional Pendidik dan Pengembang Pendidikan Indonesia,hlm (584-587).

Martinus, Y. 2001. Kamus Kata Serapan. Jakarta: Gramedia Pustaka Utama.

Munir, M. 2013. Multimedia: Konsep dan Aplikasi dalam Pendidikan. Bandung: Alfabeta.

Mulyono. (2019) "Pembelajaran Pendidikan Agama Islam Berbasis Multikultural" ElWasathiya: Jurnal Studi Agama,Volume 1, hlm (45-62).

Natalia,dkk. (2018). "Pengaruh Pelatihan Passing Bola Tak Bergerak Dengan Passing Bola Bergerak Terhadap Keterampilan Passing Bawah Siswa Ekstrakurikuler Bola Voli" E-journal Universitas Pendidikan Ganesha,Volume 9, nomor 1.

Nuril, ahmadi.2007 Panduan Olahraga Bolavoli. Solo : Era Pustaka Utama.

Puja, dkk. (2017) "Pengaruh Penerapan Model Pembelajaran
Kooperatif Tipe Numbered Head Togrther Terhadap Hasil belajar Teknik Dasar Passing Bolavoli”. Jurnal Pendidikan Jasmani, Olahraga dan Kesehatan Undiksha.

Setyosari, Punaji. 2015. Metode Penelitian Pendidikan dan Pengembangan. Jakarta: Prenamedia Grup.

Syatria, dkk. (2019). "Peningkatan Keterampilan Passing Bawah Bola Voli Melalui Metode Pembelajaran Kooperatif" Jurnal Ilmu Pendidikan, Volume 15, nomor 2, hlm (141-152).

Soeparno. 1988. Media Pengajaran Bahasa, Yogjakarta, PT. Intan Pariwara.

Suandi, dkk. 2006. Pedoman Penulisan Karya Ilmiah Tugas Akhir, Skripsi, Tesisi dan Disertasi. Singaraja: Undiksha.

Tegeh dan Jampel. 2017. Metode Penelitian Pengenbangan. Singaraja: Undiksha.

Taufiq, dkk. (2014). "Pengembangan Media Pembelajaran Ipa Terpadu Berkarakter Peduli Lingkungan Tema "Konservasi" Berpendekatan Science Edutainment". journal.unnes.ac.id. hlm (140145).

Trianto. 2009. Mendesain Model Pembelajaran Inovatif-Progreif. Surabaya: Kencana Prenada Media Grup.

Wisada, dkk. (2019).

"Pengembangan Media Video Pembelajaran Berorientasi Pendidikan Karakter". Journal of Education Technology. Volume. $3 \mathrm{hlm}$ (140-146) 
Yunus. 1992 .Olahraga Pelatihan Bolavoli. Jakarta : Departemen Pendidikan dan Kebudayaan.

Yudiana, yuyun. (2015). "Implementasi Model Pendekatan Taktik dan Teknik dalam Pembelajaran Permainan
Bola Voli pada Pendidikan Jasmani Siswa Sekolah Menengah Pertama".Jurnal Kajian Pendidikan, Volume 5, nomor 1. 